\title{
Subungual pigmented squamous cell carcinoma presenting as a grey longitudinal melanonychia in a young patient
}

\author{
Michelle Gatica-Torres, ${ }^{1}$ Lilia Arguello-Guerra, ${ }^{1}$ Juan Manuel Ruiz-Matta, ${ }^{1}$ \\ Judith Dominguez-Cherit ${ }^{2}$
}

${ }^{1}$ Instituto Nacional de Ciencias Medicas y Nutricion Salvador Zubiran, Tlalpan, Mexico ${ }^{2}$ Department of Dermatology, Instituto Nacional de Ciencias Medicas y Nutricion Salvador Zubiran, Tlalpan, Mexico

\section{Correspondence to}

Dr Judith Dominguez-Cherit, judom59@hotmail.com

Accepted 14 May 2016
CrossMark

To cite: Gatica-Torres $M$ Arguello-Guerra L, Manuel Ruiz-Matta J, et al. BMJ Case Rep Published online: [please include Day Month Year] doi:10.1136/bcr-2016215390

\section{DESCRIPTION}

A 20-year-old man was assessed for a genital ulcer that developed after an episode of orchiepididymitis. On the initial physical examination, a grey longitudinal melanonychia was found on the left index finger, measuring $4.5 \mathrm{~mm}$ in diameter, with mild subungual hyperkeratosis (figure 1A, B). A longitudinal nail biopsy was performed (figure $2 \mathrm{~A}$ ) and the histological analysis revealed a pigmented squamous cell carcinoma (SCC) (figure 2B). Total nail apparatus excision with placement of a full-thickness graft harvested from the retroauricular area was performed with no recurrence after 1-year follow-up.

Pigmented SCC of the nail unit is an uncommon tumour. A $<10 \%$ of these tumours present as longitudinal melanonychia. It occurs more commonly after the fifth decade of life, ${ }^{1}$ and only a few reports on young patients have been previously reported. Men are affected up to twofold more than women are. ${ }^{2}$

Several risk factors have been associated with the development of subungual SCC: ultraviolet radiation exposure, repeated trauma, pesticides or arsenic exposure and human papilloma virus infection. ${ }^{2}$

Lack of awareness of this tumour leads to a delay in its diagnosis. Prompt nail biopsies of new onset or persistent melanonychias should be encouraged to exclude malignant tumours such as melanoma or pigmented SCC.

Given the rarity of this tumour, treatment guidelines have not been established. Wide surgical excision is the preferred treatment, with a relapse rate of $<5 \%$. Mohs micrographic surgery is advised for limited lateral tumours and once the tumour has

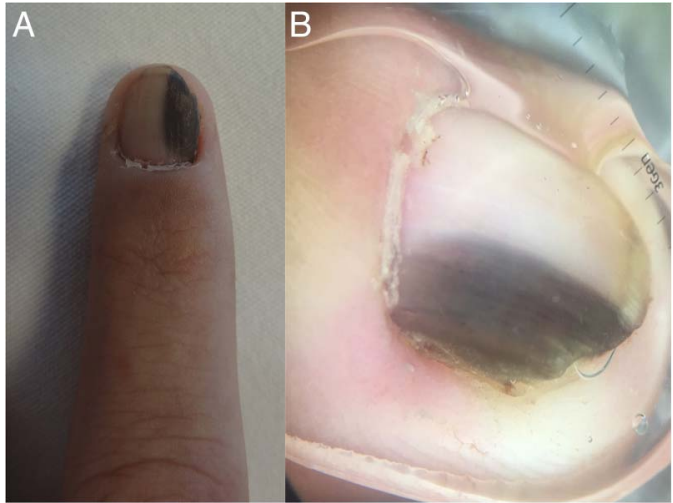

Figure 1 (A) Clinical photograph showing a longitudinal grey melanonychia of $4.5 \mathrm{~mm}$ diameter. (B) Dermoscopic view of the tumour. A curved grey melanonychia with small darker globules can be observed.

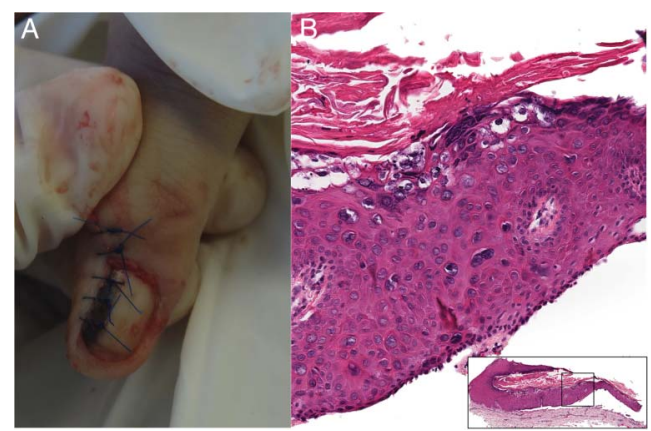

Figure 2 (A) Longitudinal nail biopsy was performed. (B) Histopatological sections show full-thickness atypia of the nail bed.

invaded bone tissue, amputation should be performed. $^{12}$

\section{Learning points}

- Ten per cent of squamous cell carcinoma (SCC) of the nail apparatus cases present as longitudinal melanonychia.

- The differential diagnosis of a longitudinal melanonychia should include benign and malignant lesions: nevi, onychomycosis, traumatic melanonychia, verruca vulgaris, melanoma and SCC.

- An early diagnosis of subungual SCC leads to more conservative surgeries, with a better functional and cosmetic outcome.

Twitter Follow Michelle Gatica- Torres at @kalygatica

Contributors MG-T and LA-G contributed to patient's follow-up and manuscript writing. JMR-M contributed to patient's surgery and follow-up, as well as to manuscript editing. JD-C contributed to manuscript editing and reference review.

Competing interests None declared.

Patient consent Obtained.

Provenance and peer review Not commissioned; externally pee reviewed.

\section{REFERENCES}

1 Lecerf $\mathrm{P}$, Richert $\mathrm{B}$, Theunis $\mathrm{A}$, et al. A retrospective study of squamous cell carcinoma of the nail unit diagnosed in a Belgian general hospital over a 15-year period. I Am Acad Dermatol 2013;69:253-61.

2 Dalle $S$, Depape L, Phan A, et al. Squamous cell carcinoma of the nail apparatus: clinicopathological study of 35 cases. Br I Dermatol 2007;156:871-4. 


\section{Images in...}

Copyright 2016 BMJ Publishing Group. All rights reserved. For permission to reuse any of this content visit http://group.bmj.com/group/rights-licensing/permissions.

BMJ Case Report Fellows may re-use this article for personal use and teaching without any further permission.

Become a Fellow of BMJ Case Reports today and you can:

- Submit as many cases as you like

- Enjoy fast sympathetic peer review and rapid publication of accepted articles

- Access all the published articles

- Re-use any of the published material for personal use and teaching without further permission

For information on Institutional Fellowships contact consortiasales@bmjgroup.com

Visit casereports.bmj.com for more articles like this and to become a Fellow 